\title{
Accuracy of FNAC in diagnosis of thyroid gland diseases
}

\author{
Chandio ${ }^{1 *}$, Shaikh $Z^{2}$, Chandio $\mathrm{K}^{1}$, Naqvi SM${ }^{1}$ and Naqvi $\mathrm{SA}^{1}$ \\ ${ }^{1}$ Department of Surgery, North Devon Health Care Service, UK \\ ${ }^{2}$ Department of Pathology, Liaquat University of Medical \& Health Sciences, Pakistan
}

\begin{abstract}
Background: Neck masses are usually benign, their clinical importance is primarily related to the need to exclude thyroid cancer Thyroid gland cancer accounts for $1 \%$ of all cancers and is responsible for $0.5 \%$ of death related to cancer. Patient age and histology as well as stage of cancer are important prognostic factors. FNAC represents a feasible, valuable screening examination.
\end{abstract}

Aim: The goal of this study was to find out the predictive value of Fine needle aspiration cytology in the evaluation of thyroid gland diseases.

Methods: This is prospective study on patient underwent FNAC because the Neck Swelling from January 2016 to December 2016 . The mean age of the patients was 33.47 years (range: $15-70$ ) accuracy rates were evaluated.

Results: On stratification of age 50(50\%) accuracy was found to be in age group of (15-30) 35(35\%) in age group of (31-35) and 9(9\%) accuracy was found in age group of (51-70) accuracy of FNAC with respect to gender accuracy was found to be 5 (71.42\%) out of 7 males and 89(95.69) out of 93 women.

Conclusion: FNAC plays useful role in the preoperative investigation of the thyroid gland diseases. The experience as well as the skills of the cytopathologist in aspiration and interpretation of aspirates will improve the practice.

\section{Background}

Neck masses are usually benign Their clinical importance is primarily related to the need to exclude thyroid cancer, which accounts for 4 to 6.5 percent of all thyroid nodules. Several different disorders can cause thyroid nodules [1-5]. Non palpable nodules (incidentalomas) have the same risk of malignancy as palpable nodules of the same size $[6,7]$. There is increasing evidence that the presence of suspicious ultrasound features is more predictive of malignancy than nodule size alone $[8,9]$. A decision analysis of thyroid nodule biopsy criteria favours the approach of selecting nodules with suspicious ultra-sonographic characteristics for biopsy over the approach of biopsy for all nodules $\geq 1 \mathrm{~cm}$ [10]. Accurate evaluation of thyroid nodules is crucial, FNAC has been used worldwide due to simplicity, safety, inexpensive, easily performed procedure in outpatient clinics leading to correct diagnosis in $>70 \%$ of cases and to clinical approach in $>90 \%$ of the cases [11] and can be used therapeutically to relieve pressure symptoms in large cyst, also play part in taking cytology to make diagnosis. Cytological examination of aspirated material can detect various thyroid conditions benign and malignant. When performed properly, the testing has a false negative rate of less than 5\%.The limitation of thyroid cytology is the inability to distinguish between benign and malignant follicular neoplasms. Around $20 \%$ of thyroid nodules with indeterminate cytology turn out to be malignant on definitive surgical pathology, therefore surgical treatment remains the standard of care.

\section{Aim}

The goal of this study was to assess the effectiveness of FNAC in the evaluation of thyroid gland diseases by comparing the results with histopathologic evaluation.

\section{Methods}

This is prospective study on patient underwent FNAC at Liaquat University of Medical \& Health Sciences, Pakistan from January 2016 to December 2016 on account of the Neck Swelling. Data were collected from Pathology department. Following information were retrieved age, gender, indications for investigations. The effectiveness/accuracy of the procedure in relation to its completeness. The diagnostic yield of pathologies (Benign/Malignant) was determined along with primary and secondary diagnosis. The specificity and sensitivity rates of cytological diagnoses were evaluated based on histopathological diagnoses. After exclusion of the no diagnostic results, cytological evaluation results were classified as positive and negative Comparing the results of cytological and histopathologic examinations, the sensitivity, specificity, positive and negative predictive value, and accuracy were calculated. These values were calculated by the following formulas. Patients with no diagnostic FNAC were excluded from the calculations

\section{Statistical analysis}

Data were analysed using the Statistical Package for Social Sciences (SPSS, version 17). Mean values were compared using the Student $t$ test. Univariate analysis of categorical variables was performed by the chi-square test. Chi-square test was used to assess the effect of gender independent variable on the results of histopathological and cytological tests, $t$-test was performed to compare the mean age between genders. Significance of the statistical tests was based on $95 \%$ confidence interval.

\section{Results}

During the study period, total hundred (100) patients were enrolled to compare the accuracy of the FNAC in the diagnosis of different categories of benign and malignant lesions with histopathology. Mean

${ }^{\star}$ Correspondence to: Chandio A, Department of Surgery, North Devon Health Care Service, UK, E-mail: chandioashfaq@yahoo.com

Received: March 30, 2018; Accepted: April 25, 2018; Published: April 27, 2018 
age of the patient was 33.47 years (Table 1) with the standard deviation of \pm 12.10 years. The minimum age of the patient was 15 years while the maximum age was 70 years. Distribution of age with normal is shown in Figure 1.

Out of 100 patients $7(7 \%)$ were male and 93 (93\%) were female (Table 2 and Figure 2).

Accuracy of FNAC was found to be 94 (94\%) (Table 3 and Figure 3).

By using chi-square test $\mathrm{P}$ value found to be highly significant i.e. $\mathrm{P}$ (0.000) between findings of FNAC and Histopathology (Figure 4). On stratification of age 50(50\%) accuracy was found to be in age group of (15-30) 35(35\%) in age group of (31-35) and 9(9\%) accuracy was found in age group of (51-70) by using chi-square test $\mathrm{P}$ value found to highly non-significant i.e. (0.853) (Tables 4 and 5). Similarly, stratification of accuracy of FNAC with respect to gender accuracy was found to be 5 (71.42\%) out of 7 males and 89(95.69) out of 93 women by using Fisher's Exact test P- value was found to be slightly non-significant (Table 5). Findings of FNAC and Histopathology (Tables 6 and 7).

\section{Discussion}

Most nodules are benign, they are usually the first sign of thyroid cancer [12]. Thyroid gland cancer accounts for $1 \%$ of all cancers and is

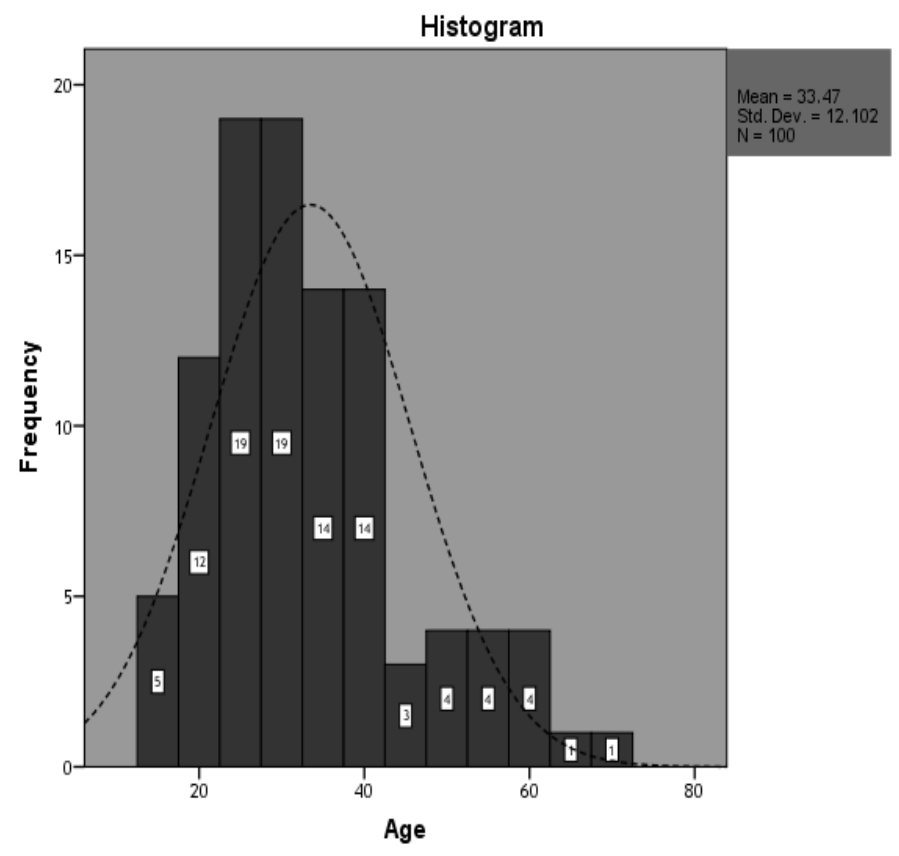

Figure 1. Graphical presentation of age $\mathrm{N}=(100)$

Table 1. Descriptive statistics of age $(\mathrm{N}=100)$

\begin{tabular}{|c|c|c|c|c|c|c|}
\hline \multirow{2}{*}{ Age in years } & Min & Max & Range & Mean & SD & $\mathbf{9 5 \%}$ C.I \\
\cline { 2 - 7 } & 15 & 70 & 55 & 33.47 & 12.10 & $31.06-35.87$ \\
\hline
\end{tabular}

Table 2. Gender distribution $\mathrm{N}=100$

\begin{tabular}{|c|c|c|}
\hline Gender & Frequency & $\%$ \\
\hline Male & 7 & $7 \%$ \\
\hline Female & 93 & $93 \%$ \\
\hline
\end{tabular}

Table 3. Accuracy of FNAC N=100

\begin{tabular}{|c|c|c|}
\hline Accuracy & Frequency & \% \\
\hline Yes & 94 & $94 \%$ \\
\hline No & 6 & $6 \%$ \\
\hline
\end{tabular}

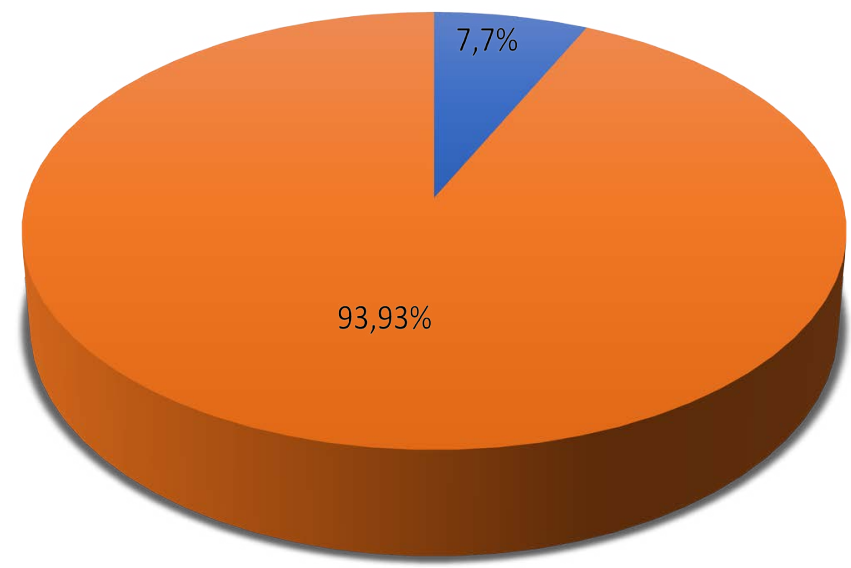

Figure 2. Graphical presentation of gender $\mathrm{N}=100$

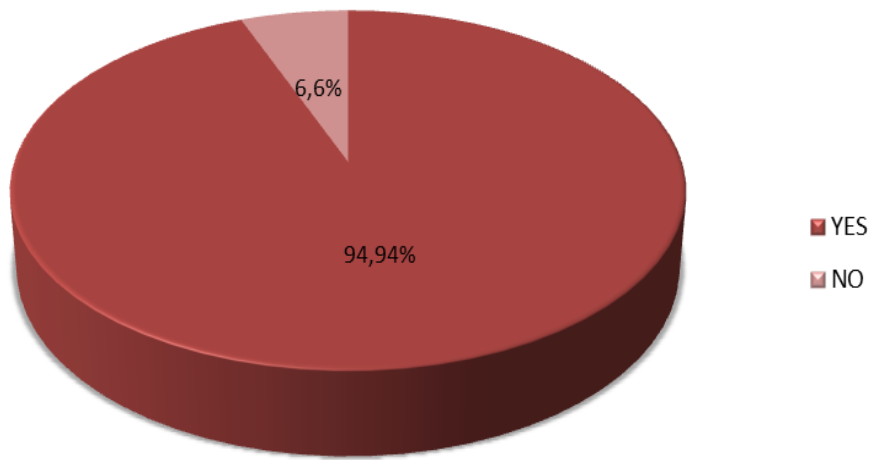

Figure 3. Graphical presentation of accuracy $\mathrm{N}=100$

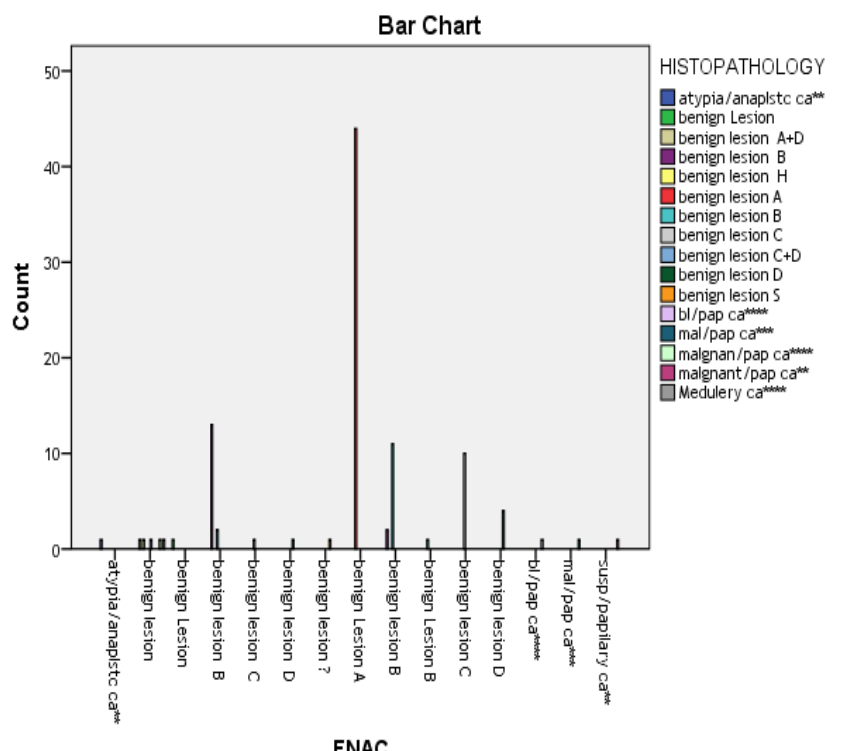

Figure 4. Comparison of findings of FNAC \& histopathology N=100 Chi-Square $=1052.694$ $\mathrm{P}=0.000$

responsible for $0.5 \%$ of death related to cancer [13]. Patient age and histology as well as stage of cancer are important prognostic factors [14].

FNAC was first used for cytological diagnosis by Martin and Ellis in 1930 [15] many studies have been carried out in the following years; 
Table 4. Stratification of accuracy with respect to age group N=100 (Applying Chisquare test)

\begin{tabular}{|c|c|c|c|}
\hline \multirow{2}{*}{ Age group } & \multicolumn{2}{|c|}{ Accuracy of FNAC } & \multirow{2}{*}{ P-value } \\
\cline { 2 - 3 } & Yes & No & \multirow{2}{*}{0.853} \\
\hline $15-30$ & 50 & 3 & \\
\hline $31-50$ & 35 & 2 & \\
\hline $51-70$ & 9 & 1 & \\
\hline
\end{tabular}

Table 5. Stratification of accuracy with respect to gender N=100 (Applying Fisher's Exact test)

\begin{tabular}{|c|c|c|c|}
\hline \multirow{2}{*}{ Gender } & \multicolumn{2}{|c|}{ Accuracy of FNAC } & P-value \\
\cline { 2 - 3 } & Yes & No & \multirow{2}{*}{0.055} \\
\hline Male & 5 & 2 & \\
\hline
\end{tabular}

Table 6. Findings of FNAC N=100

\begin{tabular}{|c|c|c|c|}
\hline \multicolumn{2}{|c|}{ Findings } & \multirow{2}{*}{$\begin{array}{c}\text { Frequency } \\
1\end{array}$} & \multirow{2}{*}{$\begin{array}{c}\text { Percent } \\
1.0\end{array}$} \\
\hline \multirow{16}{*}{ Valid } & $\begin{array}{l}\text { atypia/anaplastic } \\
\text { ca** }^{* *}\end{array}$ & & \\
\hline & benign lesion & 5 & 5.0 \\
\hline & benign Lesion & 1 & 1.0 \\
\hline & benign lesion $\mathrm{B}$ & 15 & 15.0 \\
\hline & benign lesion $\mathrm{C}$ & 1 & 1.0 \\
\hline & benign lesion $\mathrm{D}$ & 1 & 1.0 \\
\hline & benign lesion? & 1 & 1.0 \\
\hline & benign Lesion $\mathrm{A}$ & 44 & 44.0 \\
\hline & benign lesion $\mathrm{B}$ & 13 & 13.0 \\
\hline & benign Lesion $\mathrm{B}$ & 1 & 1.0 \\
\hline & benign lesion $\mathrm{C}$ & 10 & 10.0 \\
\hline & benign lesion $\mathrm{D}$ & 4 & 4.0 \\
\hline & bl/pap ca**** & 1 & 1.0 \\
\hline & $\mathrm{mal} / \mathrm{pap} \mathrm{ca}^{* * *}$ & 1 & 1.0 \\
\hline & susp/papillary ca** & 1 & 1.0 \\
\hline & Total & 100 & 100.0 \\
\hline
\end{tabular}

Table 7. Findings of histopathology $n=100$

\begin{tabular}{|c|c|c|c|}
\hline \multicolumn{2}{|c|}{ Findings } & \multirow{2}{*}{$\begin{array}{c}\text { Frequency } \\
1\end{array}$} & \multirow{2}{*}{$\begin{array}{c}\text { Percent } \\
1.0\end{array}$} \\
\hline \multirow{17}{*}{ Valid } & $\begin{array}{l}\text { atypia/anaplastic } \\
\text { ca** }^{* *}\end{array}$ & & \\
\hline & benign Lesion & 1 & 1.0 \\
\hline & benign lesion $\mathrm{A}+\mathrm{D}$ & 1 & 1.0 \\
\hline & benign lesion $\mathrm{B}$ & 15 & 15.0 \\
\hline & benign lesion $\mathrm{H}$ & 1 & 1.0 \\
\hline & benign lesion $\mathrm{A}$ & 44 & 44.0 \\
\hline & benign lesion $\mathrm{B}$ & 14 & 14.0 \\
\hline & benign lesion $\mathrm{C}$ & 11 & 11.0 \\
\hline & benign lesion $\mathrm{C}+\mathrm{D}$ & 1 & 1.0 \\
\hline & benign lesion $\mathrm{D}$ & 5 & 5.0 \\
\hline & benign lesion $\mathrm{S}$ & 1 & 1.0 \\
\hline & bl/pap ca**** & 1 & 1.0 \\
\hline & $\mathrm{mal} / \mathrm{pap} \mathrm{ca}^{* * *}$ & 1 & 1.0 \\
\hline & $\begin{array}{l}\text { Malignant/pap } \\
\mathrm{ca}^{* * * *}\end{array}$ & 1 & 1.0 \\
\hline & $\begin{array}{l}\text { malignant/pap } \\
\text { ca** }^{* *}\end{array}$ & 1 & 1.0 \\
\hline & Medullary ca**** & 1 & 1.0 \\
\hline & Total & 100 & 100.0 \\
\hline
\end{tabular}

however; the method has been widely used after 1952 [16]. First paper on thyroid FNAC dates to 1987 by Rege, et al. [17]. Fine-needle aspiration cytology is an easy, cost-effective test for diagnosis of cancer, its use has markedly decreased the number of unnecessary surgeries [18]. FNAC is the preferred diagnostic method for the initial stage of evaluation of thyroid nodules [19]. It helps in triaging patients for conservative management or surgical intervention, despite its recognized interest, it has various drawbacks, such as incomplete aspiration, false negative and false positive and inability to distinguish follicular adenoma from carcinoma [20,21]. The adequacy depends not only upon the nature of the lesion but also upon the aspirator, constant practice is the only way of developing expertise. The sensitivity and specificity ratios for FNAC in published series range between $65 \%$ and $98 \%$ for sensitivity and 73 $100 \%$ for specificity [22-26]. In this study, we found the sensitivity of $94 \%$ this contrasts with other studies. Saddique in his study showed sensitivity of $75 \%$, specificity of $95.83 \%$ [25]. Kumar in his study revealed sensitivity of $77 \%$ and specificity of 100 [26]. The major reason for the wide range of sensitivity and specificity ratios is the differences in the categorization of lesion, some authors categorize follicular lesions as histopathological benign, while others categorize these lesions as malignant $[12,22,23,27,28]$. The factors that reduce the efficiency of FNAC include, inadequate sampling, inexperience, natural difficulties of differentiation of nature of the lesion benign and malignant follicular lesions, cellularity expected is related to the type of lesion, for example, cyst fluid may contain no thyroid epithelial cells but would still be considered adequate, whereas an aspirate from a solid nodule would need to contain moderately-sized groups of epithelial cells. The role of FNAC in the evaluation of thyroid nodules is now well established, and has become the initial test as it is safe and cost effective and has become a standard test. An adequate and good quality specimen is considered diagnostic or satisfactory. A benign cytologic diagnosis is reported $50 \%$ to $90 \%$ (average, $70 \%$ ) [26,29-32]. $10 \%$ to $30 \%$ of FNAC specimens could be suspicious for malignancy (indeterminate) (average, 20\%) [26,29]. A malignant cytologic diagnosis varies from $1 \%$ to $10 \%$ (average, 5\%). Caruso and Mazzaferri [29] reported the results from 9 series that included more than 9,000 patients: benign, $74 \%$; malignant, $4 \%$; inadequate, $11 \%$; and suspicious, $11 \%$. False-negative rates generally vary from $1.5 \%$ to $11.5 \%$ (average, $<5 \%$ ) [29,33-35]. The frequency of false-negative cytologic diagnosis depends on the number of patients who subsequently have surgery and histologic review. In most retrospective series, less than $10 \%$ of patients with a benign cytologic diagnosis subsequently have thyroid surgery, suggesting that false-negative rates should be interpreted with some scepticism $[26,29]$, most specialists agree that if all the patients have thyroid surgery the true false-negative rate is less than $5 \%$. False-negative rates are lower in centres with cytologic interpretation by expert cytopathologists. A false-positive diagnosis indicates that a patient with a malignant FNA result was found on histologic examination to have benign lesions. Falsepositive rates vary from $0 \%$ to $8 \%$ (average, $3 \%$ ) [26,29,34]. Sampling errors account for false diagnoses [26,35-37]. Improper or inadequate sampling accounts for some false-negative errors, nodules smaller than $1 \mathrm{~cm}$ may be too small for accurate needle placement, and nodules larger than $4 \mathrm{~cm}$ are too large to allow proper sampling from all areas, thereby increasing the likelihood of misdiagnosis. Accurate cytological evaluation of thyroid nodules is crucial for maximizing the benefits of a medical therapy rather than the risk of an unnecessary surgery. FNAC, leading to a correct diagnosis in more than $70 \%$ of the cases in general population, represents the gold standard for achieving the appropriate management and reducing the number of benign nodules undergoing thyroid surgery [5,38-41]. limitation found in the present study was the high rate of 'unrepresentative' samples. The drawbacks of cytology in thyroid pathology mostly lie in the "suspicious" group, dominated by Oncocytic and micro vesicular lesions in which positive diagnosis depends on purely histological criteria. The technique however remains useful. 


\section{Conclusion}

Thus, to summarise, this study found that FNAC plays a useful role in the preoperative investigation of the thyroid gland diseases. The experience, as well as the skills of the cytopathologist in aspiration and interpretation, is crucial. Fine needle aspiration is a good predictor of malignancy which results in a smaller proportion of excisions for benign nodules.

\section{References}

1. Werk EE Jr, Vernon BM, Gonzalez JJ, Ungaro PC, McCoy RC (1984) Cancer in thyroid nodules. A community hospital survey. Arch Intern Med 144: 474. [Crossref]

2. Belfiore A, Giuffrida D, La Rosa GL, Ippolito O, Russo G, et al. (1989) High frequency of cancer in cold thyroid nodules occurring at young age. Acta Endocrinol (Copenh) 121: 197-202. [Crossref]

3. Hegedüs L (2004) Clinical practice. The thyroid nodule. N Engl J Med 351: 1764-1771. [Crossref]

4. Lin JD, Chao TC, Huang BY, Chen ST, Chang HY, et al. (2005) Thyroid cancer in the thyroid nodules evaluated by ultrasonography and fine-needle aspiration cytology. Thyroid 15: 708-717. [Crossref]

5. Kwong N, Medici M, Angell TE, Liu X, Marqusee E, et al. (2015) The influence of patient age on thyroid nodule formation, multinodularity, and thyroid cancer risk. JClin Endocrinol Metab 100: 4434. [Crossref]

6. Hagag P, Strauss S, Weiss M (1998) Role of ultrasound-guided fine-needle aspiration biopsy in evaluation of nonpalpable thyroid nodules. Thyroid 8: 989-995. [Crossref]

7. Nam-Goong IS, Kim HY, Gong G, Lee HK, Hong SJ, et al. (2004) Ultrasonographyguided fine-needle aspiration of thyroid incidentaloma: correlation with pathological findings. Clin Endocrinol (Oxf) 60: 21-28. [Crossref]

8. Leenhardt L, Hejblum G, Franc B, Fediaevsky LD, Delbot T, et al. (1999) Indications and limits of ultrasound-guided cytology in the management of nonpalpable thyroid nodules. J Clin Endocrinol Metab 84: 24-28. [Crossref]

9. Papini E, Guglielmi R, Bianchini A, Crescenzi A, Taccogna S, et al. (2002) Risk of malignancy in nonpalpable thyroid nodules: predictive value of ultrasound and colorDoppler features. J Clin Endocrinol Metab 87: 1941-1946. [Crossref]

10. McCartney CR, Stukenborg GJ (2008) Decision analysis of discordant thyroid nodule biopsy guideline criteria. J Clin Endocrinol Metab 93: 3037-3044. [Crossref]

11. Rossi ED, Morassi F,Santeusanio G, Zannoni GF, Fadda G (2010) Thyroid fine needle aspiration cytology processed by thin prep: An additional slide decreased the number of inadequate results. Cytopathology 21: 97-102. [Crossref]

12. Esmaili HA, Taghipour H (2012) Fine-needle aspiration in the diagnosis of thyroid diseases: An appraisal in our institution. ISRN Pathology 2012: 912728.

13. Roman SA (2003) Endocrine tumors: Evaluation of the thyroid nodule. Curr Opin Oncol 15: 66-70. [Crossref]

14. Larijani B, Aghakhani S, Haghpanah V, Mosavi-Jarrahi A, Bastanhagh M (2005) Review of thyroid cancer in Iran. Aus-Asian J Cancer 4: 199-203.

15. Martin HE, Ellis EB (1930) biopsy by needle puncture and aspiration. Ann Surg 92: 169-181. [Crossref]

16. Soderstrom N (1952) Puncture of goiters for aspiration biopsy. Acta Med Scand 144: 237-244. [Crossref]

17. Rege JD, Nath AR, Bijlani JC, Trivedi DR, Deshpande DV (1987) Fine needle aspiration cytology in solitary cold nodules of thyroid. J Assoc Physicians India 35: 819-821. [Crossref]

18. Rege JD, Nath AR, Bijlani JC, Trivedi DR, Deshpande DV (1987) Fine needle aspiration cytology in solitary cold nodules of thyroid. $J$ Assoc Physicians India 35: 819-821. [Crossref]
19. Cibas ES, Ali SZ; NCI Thyroid FNA State of the Science Conference (2009) The bethesda system for reporting thyroid cytopathology. Am J Clin Pathol 132: 658-665. [Crossref]

20. Bagga PK, Mahajan NC (2010) Fine needle aspiration cytology of thyroid swellings: How useful and accurate is it? Indian J Cancer 47: 437-442. [Crossref]

21. Bajaj Y, De M, Thompson A (2006) Fine needle aspiration cytology in diagnosis and management of thyroid disease. J Laryngol Otol 120: 467-469. [Crossref]

22. Ko HM, Jhu IK, Yang SH, Lee JH, Nam JH, et al. (2003) Clinicopathologic analysis of fine needle aspiration cytology of the thyroid. A review of 1,613 cases and correlation with histopathologic diagnoses. Acta Cytol 47: 727-732. [Crossref]

23. Pandey P, Dixit A, Mahajan NC (2012) Fine-needle aspiration of the thyroid: A cytohistologic correlation with critical evaluation of discordant cases. Thyroid Res Pract 9: 32-9.

24. Bagga PK, Mahajan NC (2010) Fine needle aspiration cytology of thyroid swellings: how useful and accurate is it? Indian J Cancer 47: 437-442. [Crossref]

25. Haberal AN, Toru S, Ozen O, Arat Z, Bilezikçi B (2009) Diagnostic pitfalls in the evaluation of fine needle aspiration cytology of the thyroid: correlation with histopathology in 260 cases. Cytopathology 20: 103-108. [Crossref]

26. Amrikachi M, Ramzy I, Rubenfeld S, Wheeler TM (2001) Accuracy of fine-needle aspiration of thyroid. Arch Pathol Lab Med 125: 484-488.

27. Gharib H, Goellner JR (1993) Fine-needle aspiration biopsy of the thyroid: an appraisal Ann Intern Med 118: 282-289. [Crossref]

28. Saddique M, Islam U U, Iqbal P, Baloch QU (2008) FNAC: A reliable diagnostic tool in solitary thyroid nodule and multinodular goiter. Pak J Surg 24: 188-191.

29. Kumar S, Aqil S, Dahar A (2008) Role of fine needle aspiration cytology in thyroid diseases. J Surg Pak 13: 22-25.

30. Caruso D, Mazzaferri EL (1991) Fine needle aspiration biopsy in the management of thyroid nodules. Endocrinologist 1: 194-202. [Crossref]

31. Baloch ZW, Sack MJ, Yu GH, Livolsi VA, Gupta PK (1998) Fine-needle aspiration of thyroid: an institutional experience. Thyroid 8: 565-569. [Crossref]

32. Goellner JR, Gharib H, Grant CS, Johnson DA (1987) Fine needle aspiration cytology of the thyroid, 1980 to 1986. Acta Cytol 31: 587-590. [Crossref]

33. Singer PA (1996) Evaluation and management of the solitary thyroid nodule. Otolaryngol Clin North Am 29: 577-591. [Crossref]

34. Hamburger JI (1994) Diagnosis of thyroid nodules by fine needle biopsy: use and abuse. J Clin Endocrinol Metab. 79: 335-339. [Crossref]

35. Giuffrida D, Gharib H (1995) Controversies in the management of cold, hot, and occult thyroid nodules. Am J Med 99: 642-650. [Crossref]

36. Hall TL, Layfield LJ, Philippe A, Rosenthal DL (1989) Sources of diagnostic error in fine needle aspiration of the thyroid. Cancer 63: 718-725. [Crossref]

37. Solomon D (1993) Fine needle aspiration of the thyroid: an update. Thyroid today 16 1-9. [Crossref]

38. Oertel YC (1996) Fine-needle aspiration and the diagnosis of thyroid cancer. Endocrinol Metab Clin North Am 25: 69-91. [Crossref]

39. Rossi ED, Raffaelli M, Minimo C, Mule A, Lombardi CP, et al. (2005) Immunocytochemical evaluation of thyroid neoplasms on thin-layer smears from fineneedle aspiration biopsies. Cancer 105: 87-95. [Crossref]

40. Fadda G, Rossi ED, Raffaelli M, Pontecorvi A, Sioletic S, et al. (2011) Follicular thyroid neoplasms can be classified as low- and high-risk according to HBME-1 and Galectin-3 expression on liquid-based fine-needle cytology. Eur J Endocrinol 165: 447453. [Crossref]

41. Faquin WC, Baloch ZW (2010) Fine-needle aspiration of follicular patterned lesions of the thyroid: Diagnosis, management, and follow-up according to National Cancer Institute (NCI) recommendations. Diagn Cytopathol 38: 731-739. [Crossref]

Copyright: $\odot 2018$ Chandio A. This is an open-access article distributed under the terms of the Creative Commons Attribution License, which permits unrestricted use, distribution, and reproduction in any medium, provided the original author and source are credited. 